\title{
A PROJEÇÃO ESPECULAR DE UMA NOVA TEORIA DA ALMA HUMANA
}

\author{
Jaison Luís Crestani \\ Universidade Estadual Paulista \\ Assis (SP), Brasil
}

\begin{abstract}
Resumo: Na tradição dos estudos machadianos, o conto "O espelho" tende a ser apreciado criticamente por uma perspectiva de leitura que legitima a suposta seriedade do discurso arbitrário do narradorpersonagem Jacobina. Sob esse ângulo, o conto é entendido em chave filosófica, existencial e psicológica, e as extravagantes teorias metafísicas de Jacobina são consideradas como uma demonstração válida e autêntica da essência humana. Desse modo, na tentativa de contornar essas distorções interpretativas, este trabalho propõe uma redefinição das perspectivas de análise com o intuito de priorizar a apreciação dos procedimentos estruturais, que mobilizam uma ironia estratégica empenhada em desqualificar esse narrador e em satirizar o conteúdo de suas investigações metafísicas.
\end{abstract}

Palavras-chave: contos; narrador; ironia; sátira.

\section{The mirror projection: a new theory of the human soul}

\begin{abstract}
In the tradition of Machadian studies, the short story "O espelho" tends to be analysed in a critical perspective that legitimizes the supposed seriousness of the arbitrary speech of the narratorcharacter Jacobina. From this point of view, the narrative is understood according to philosophical, existential and psychological standards, and the extravagant metaphysical theories of Jacobina are considered as a valid and authentic demonstration of the human essence. Trying to overcome these interpretative distortions, this paper proposes a redefinition of critical perspectives in order to give priority to the analysis of structural procedures that mobilize a strategic irony with the aim of disqualifying this narrator-character and satirizing the content of his metaphysical investigations.
\end{abstract}

Keywords: short stories; narrator; irony; satire. 


\section{Papéis avulsos: unidade na diversidade}

A composição do volume Papéis avulsos (1882) remete a um período de transição da carreira de Machado de Assis, no que diz respeito tanto à mudança de vínculos jornalísticos quanto à suposta passagem a um novo estilo de expressão literária, que corresponderia à maturidade artística do autor. A composição versátil e multiforme do volume instiga a discussão sobre a questão da unidade da obra, composta por textos provenientes de diferentes contextos e datas de publicação. O paradoxo entre unidade e diversidade fora lançado pelo próprio autor ainda em outubro de 1882, na "Advertência" que abre o volume:

Este título de Papéis avulsos parece negar ao livro uma certa unidade; faz crer que o autor coligiu vários escritos de ordem diversa para o fim de os não perder. A verdade é essa, sem ser bem essa. Avulsos são eles, mas não vieram aqui como passageiros, que acertam de entrar na mesma hospedaria. São pessoas de uma só família, que a obrigação do pai fez sentar à mesma mesa. ${ }^{1}$

O sentido que se depreende dos entretons e das considerações ambivalentes presentes no trecho citado ("certa unidade"; "vários escritos de ordem diversa"; "A verdade é essa, sem ser bem essa"; "Avulsos são eles, mas [...] pessoas de uma só família") é o de que o próprio autor optou pela manutenção da irresolução desse paradoxo, deixando que cada leitor se posicionasse à sua maneira, conforme indicam as suas palavras no parágrafo seguinte: "O livro está nas mãos do leitor". A conciliação de elementos contrários e diversos perpassa também a constituição genérica do conjunto de narrativas reunidas: "há aqui páginas que parecem meros contos, e outras que não o são". Entre o parecer e o não ser permanece uma vez mais a indefinição, que sugere uma dubiedade conscientemente construída.

O paradoxo que circunda a unidade do livro é acentuado ainda mais pela diversidade das modalidades estilísticas empregadas na composição dos trabalhos inseridos no volume: narrativas fantásticas, teorias extravagantes, paródias, pastiches, retratos, anedotas. Desse modo, pode-se considerar que a sátira menipeia constitui o

\footnotetext{
${ }^{1}$ ASSIS, Machado de. Papéis avulsos. Rio de Janeiro: Tipografia e litografia a vapor. Encadernação e Livraria Lombaerts \& C., 1882. p. i.
} 
elemento responsável por conferir unidade à versatilidade do volume Papéis avulsos. De acordo com a indicação de Ivan Teixeira, "o efeito de dispersão de elementos avulsos coloca-se como um dos propósitos do livro, que, com a diversidade de seu corpo extravagante, procura produzir a sensação de desvario da existência". ${ }^{2}$ Assim, a conexão entre a forma narrativa desses textos machadianos com os procedimentos literários da sátira menipeia proporciona uma compreensão mais eficaz dos efeitos de sentido propostos nessa coletânea, construída com base numa insistente combinação entre a gravidade da apresentação narrativa e a representação fantasiosa de situações absurdas e extravagantes - técnica característica das obras de Luciano de Samósata, cujo efeito humorístico é alcançado, muitas vezes, por meio da "simples atribuição de gravidade estilística a uma questão totalmente absurda". ${ }^{3}$

Articulando uma miscelânea de formas discursivas, apropriadas e parodiadas da cultura geral, a coletânea Papéis avulsos empenha-se na distorção de conceitos absolutistas e na desconstrução de verdades estabelecidas. Sob essa perspectiva, as essências do homem são caracterizadas como noções construídas de acordo com as conveniências da pragmática social.

$\mathrm{Na}$ tradição dos estudos machadianos, a relação entre a sátira menipeia e a ficção de Machado de Assis foi demonstrada fundamentalmente por três críticos literários: José Guilherme Merquior, Enylton de Sá Rego e Ivan Teixeira. No ensaio "Gênero e estilo nas Memórias póstumas de Brás Cubas" (1972), Merquior inaugura o estudo dessas conexões, salientando a "fusão de humorismo filosófico e fantástico" que tornaria o primeiro romance maduro do autor "um representante moderno do gênero cômico-fantástico, também conhecido como literatura menipeia". ${ }^{4}$ Amparado nos estudos de Mikhail Bakhtin a respeito da obra de Rabelais e de Dostoievski, Merquior destaca os cinco atributos principais dessa linhagem literária, que seriam apropriados pela obra madura de Machado de Assis: a) a ausência de qualquer distanciamento

\footnotetext{
2 TEIXEIRA, Ivan. Pássaro sem asas ou morte de todos os deuses. Uma leitura de Papéis avulsos. In: ASSIS, Machado de. Papéis avulsos. Edição e introdução de Ivan Teixeira. São Paulo: Martins Fontes, 2005. p. xxii.

3 "[...] the straightforward application of the historian's techniques to a totally absurd topic" (ROBINSON, Christopher. Lucian and his influence in Europe. London: Duckworth, 1979. p. 25. Tradução minha).

${ }^{4}$ MERQUIOR, José Guilherme. Gênero e estilo nas Memórias póstumas de Brás Cubas. In: ASSIS, Machado de. Obra completa em quatro volumes. v. 1. São Paulo: Aguilar, 2008. p. 140.
} 
enobrecedor na figuração dos personagens e de suas ações; b) a mistura do sério e do cômico, de que resulta uma abordagem humorística das questões mais cruciais: o sentido da realidade, o destino do homem, a orientação da existência etc.; c) a absoluta liberdade do texto em relação aos ditames da verossimilhança; d) a frequência da representação literária de estados psíquicos aberrantes: desdobramentos da personalidade, paixões descontroladas, delírios; e) uso constante de gêneros intercalados. $^{5}$

Em $O$ calundu e a panaceia: Machado de Assis, a sátira menipeia e a tradição luciânica (1989), Enylton de Sá Rego aprofunda as sugestões de Merquior, promovendo uma revisão das limitadas concepções teóricas a respeito da sátira menipeia, provenientes dos trabalhos de Bakhtin, e amplia o estudo dos precursores dessa linhagem literária, examinando especialmente as obras dos antecessores de Laurence Sterne, tais como: Sêneca, Luciano, Erasmo e Burton. Partindo desse exame, o estudioso concentra-se na análise das relações que se evidenciam entre a ficção machadiana e a tradição luciânica, explorando principalmente a assimilação dos seguintes procedimentos técnicos: "a anatomia e o paradoxo; a paródia e o uso de citações truncadas; o ponto de vista do observador distanciado e o falso pessimismo". 6 Como resultados da apropriação da sátira menipeia, o crítico destaca:

[...] é através do uso sistemático da paródia que os textos associados à tradição luciânica apresentam um hibridismo genérico que lhes serve na superação das formas literárias estabelecidas. Além de seu conteúdo parodístico, tais textos caracterizam-se ainda pela presença de um narrador irônico e distanciado, por uma posição moral essencialmente antiautoritária e por uma extrema liberdade de imaginação frente aos ditames da verossimilhança. ${ }^{7}$

Ivan Teixeira, por sua vez, examina esse diálogo machadiano com a tradição menipeia em diversos trabalhos, a começar por Apresentação de Machado de Assis (1987), que se mantém ainda circunscrito à aplicação do conceito bakhtiniano de

\footnotetext{
${ }^{5}$ Ibidem.

${ }^{6}$ REGO, Enylton de Sá. O calundu e a panaceia: Machado de Assis, a sátira menipeia e a tradição luciânica. Rio de Janeiro: Forense Universitária, 1989. p. 105.

${ }^{7}$ Idem, p. 165-166.
} 
carnavalização e ao aprofundamento das sugestões de Merquior sobre a fusão de humor filosófico e fantástico em Memórias póstumas de Brás Cubas. Em trabalhos posteriores, "Pássaro sem asas ou morte de todos os deuses. Uma leitura de Papéis avulsos" (2005) e $O$ altar e o trono: dinâmica do poder em O alienista (2010), o crítico amplia consideravelmente o esboço conceitual a respeito dos procedimentos da sátira menipeia e da sua apropriação pela obra machadiana. De acordo com Ivan Teixeira, essa tendência criativa pressupõe o abandono do equilíbrio previsto pelos gêneros puros da tradição clássica, a combinação extravagante de elementos contrários, o humor disparatado e a paródia ou imitação burlesca das formas consagradas da cultura. Para o crítico, os reflexos do investimento machadiano na apropriação dessa linhagem literária constituem "a diretriz construtiva de Memórias póstumas de Brás Cubas e Papéis avulsos - verdadeiros programas de uma incrível investigação alegórico-fantástica dos modos de comunicação social do Segundo Reinado brasileiro". ${ }^{8}$ Fundamentada nessas combinações extravagantes, a apropriação machadiana dos procedimentos da sátira menipeia institui o absurdo como equilíbrio, vinculando-se à "tópica camoniana do desconcerto do mundo" e à "lógica do paradoxo, que tanto afirma por negativas quanto nega por afirmações". 9

Assim, com base nessa fortuna crítica, este trabalho propõe uma leitura do conto "O espelho" com o intuito de investigar o investimento machadiano na assimilação e apropriação dos procedimentos criativos da tradição da sátira menipeia. Com base na análise de suas soluções formais, pretende-se examinar a desqualificação irônica que a performance enunciativa do autor implícito imprime à matéria enunciada pelo narrador-personagem. ${ }^{10}$

\footnotetext{
${ }^{8}$ TEIXEIRA, Ivan. Pássaro sem asas ou morte de todos os deuses. Uma leitura de Papéis avulsos, cit., p. xxvii-xxviii.

${ }^{9}$ TEIXEIRA, Ivan. $O$ altar e o trono: dinâmica do poder em $O$ alienista. São Paulo: Ateliê Editorial; Editora da Unicamp, 2010. p. 151.

${ }^{10}$ Para uma análise da constituição versátil e multiforme do volume Papéis avulsos, conferir: CRESTANI, Jaison Luís. O percurso criativo: do periódico ao livro. In:__. Machado de Assis e o processo de criação literária: estudo comparativo das narrativas publicadas n'A Estação (1879-11884), na Gazeta de Notícias (1881-1884) e nas coletâneas Papéis avulsos (1882) e Histórias sem data (1884). 2011. 363 fls. Tese (Doutorado em Literatura Brasileira). Faculdade de Ciências e Letras - UNESP Assis, 2011.
} 


\section{A projeção especular de uma nova teoria da alma humana}

Publicado inicialmente na Gazeta de Notícias em 8 de setembro de 1882, o conto "O espelho" apresenta-se como um "esboço de uma nova teoria da alma humana", formulado no contexto de uma reunião de um grupo de amigos que debatiam "questões de alta transcendência". Em sua organização formal, destaca-se a convivência de dois narradores que se alternam no desempenho da função enunciativa: numa primeira instância, o autor implícito descreve o cenário das discussões metafísicas e caracteriza os seus agentes; na sequência, a narração é transferida para a voz da personagem Jacobina, que relata uma experiência pessoal dos seus 25 anos com o intuito de comprovar a sua teoria da alma humana.

Em sua exposição, Jacobina defende a tese de que "cada criatura humana traz duas almas consigo: uma que olha de dentro para fora, outra que olha de fora para dentro...". Portanto, uma alma interior e outra exterior, que coexistem e se complementam:

Está claro que o ofício dessa segunda alma é transmitir a vida, como a primeira; as duas completam o homem, que é, metafisicamente falando, uma laranja. Quem perde uma das metades, perde naturalmente metade da existência; e casos há, não raros, em que a perda da alma exterior implica a da existência inteira. ${ }^{11}$

Apresentados os postulados de sua concepção metafísica, Jacobina detém-se na narração de um episódio de sua vida pessoal a fim de legitimar a sua proposição. Depois de uma infância pobre, Jacobina relata a sua excepcional nomeação ao posto de alferes da Guarda Nacional - acontecimento que inspirou o orgulho da família e desencadeou uma série de lisonjas e regalias. Opera-se, assim, uma transformação no jovem rapaz, que deixa de ser o "Joãozinho" do passado para tornar-se o "senhor alferes".

Em visita à fazenda de sua tia, D. Marcolina, o alferes recém-nomeado foi recebido com exagerada cortesia e "rapapés": "era alferes para cá, alferes para lá, alferes a toda a hora". Na mesa, "tinha o melhor lugar, e era o primeiro servido". Em seu

\footnotetext{
${ }^{11}$ ASSIS, Machado de. Obra completa. 4. ed. v. 2. Rio de Janeiro: Aguilar, 1979. p. 346.
} 
quarto, a tia fez questão de colocar um grande espelho, "obra rica e magnífica", que destoava da simplicidade do restante da mobília da casa:

Era um espelho que lhe dera a madrinha, e que esta herdara da mãe, que o comprara a uma das fidalgas vindas em 1808 com a corte de D. João VI. Não sei o que havia nisso de verdade; era a tradição. O espelho estava naturalmente muito velho; mas via-se-lhe ainda o ouro, comido em parte pelo tempo, uns delfins esculpidos nos ângulos superiores da moldura, uns enfeites de madrepérola e outros caprichos do artista. Tudo velho, mas bom... ${ }^{12}$

Estimulada por essas regalias, a transformação deu-se por completo: "No fim de três semanas, era outro, totalmente outro". As atenções, carícias e obséquios obliteraram a consciência de sua humanidade e firmaram o domínio exclusivo da alma exterior, alimentada pelo exercício do posto de alferes. Em uma incisiva autoanálise de sua condição, constata que "o alferes eliminou o homem". Jacobina não contava, porém, com uma viagem repentina da tia em função do adoecimento de sua filha, que o obrigou a permancer sozinho na fazenda. Ainda nos primeiros dias, foi surpreendido também com uma fuga conjunta dos escravos, e a sua solidão adquiriu proporções imensuráveis: "As horas batiam de século a século no velho relógio da sala, cuja pêndula, tic-tac, tictac, feria-me a alma interior, como um piparote contínuo da eternidade. [...] Não eram golpes de pêndula, era um diálogo do abismo, um cochicho do nada". ${ }^{13}$

$\mathrm{Na}$ tentativa de amenizar os efeitos da ausência do olhar do outro, Jacobina dedica-se inutilmente à leitura, escrita, declamação de versos, ginástica, sem nada alcançar. Ao contemplar-se no requintado espelho, sua imagem apareceu "vaga, esfumada, difusa, sombra de sombra". Nesse atordoamento angustiante, teve uma súbita inspiração e decidiu vestir a farda de alferes: "o vidro reproduziu então a figura integral; nenhuma linha de menos, nenhum contorno diverso; era eu mesmo, o alferes, que achava, enfim, a alma exterior". Com esse recurso infalível, Jacobina pode "atravessar mais seis dias de solidão sem os sentir...".

\footnotetext{
${ }^{12}$ ASSIS, Machado de. Obra completa. 4.ed. v. 2, cit., p. 347-348.

${ }^{13}$ Idem, p. 349.
} 
$\mathrm{Na}$ gama de estudos sobre esse conto que se consolidaram na tradição crítica, percebe-se um investimento na abordagem da crise de identidade da personagem, revelada por meio de uma "análise da mutabilidade interna e contraditória do ser humano". ${ }^{14}$ Nessa perspectiva, assinalam-se também a perda de contornos nítidos e a fragmentação da personalidade humana: "sem unidade, antes várias e complexas, muitas personagens machadianas precisam, para ter consciência de si mesmas, de se projetarem em algo de tangível, de exterior. É a 'alma exterior', que para o herói de 'O espelho', um de seus melhores contos, se resume numa farda de alferes". ${ }^{15}$

Essa duplicidade da constituição da identidade pessoal é analisada por John Gledson nas suas implicações metafóricas com a fragilidade do conceito de identidade nacional no Brasil do século XIX. Para o crítico, a tradição impressa no espelho em que Jacobina se contempla remete à herança problemática do período colonial que acompanha o país. Assim, a imagem "vaga, esfumada, difusa, sombra de sombra" de Jacobina, estampada no espelho, constituiria também uma projeção especular da precariedade da circunstância brasileira, que sinaliza "a existência duvidosa do Brasil como nação e uma sociedade dividida e corrompida pela escravatura e sua herança". ${ }^{16}$

A teoria metafísica esboçada no conto machadiano anteciparia, na visão de Paul Dixon, "os modelos fenomenológicos da consciência, com sua intersubjetividade ou implicação mútua do sujeito e do objeto". ${ }^{17}$ Essa interação seria representada no conto pela coexistência e pela relação de complementariedade que se estabelece entre a alma interior e a exterior, resultando no conceito que o crítico denomina de "lei da laranja": "O objeto e o sujeito dependem um do outro, como a fruta e a casca". ${ }^{18}$

Para Alfredo Bosi, a transformação do sujeito resultaria da ascensão social da personagem e consistiria no "aprendizado da aparência". Em sua opinião, o

\footnotetext{
${ }^{14}$ BRAYNER, Sônia. O conto de Machado de Assis. In: ASSIS, Machado de. O conto de Machado de Assis: antologia, organização e introdução de Sônia Brayner. 2.ed. Rio de Janeiro: Civilização Brasileira, 1981. p. 16.

15 PEREIRA, Lúcia Miguel. Machado de Assis (Estudo crítico e biográfico). 5. ed. São Paulo: José Olympio, 1955. p. 234.

${ }^{16}$ GLEDSON, John. A história do Brasil em Papéis avulsos, de Machado de Assis. In: Por um novo Machado de Assis: ensaios. São Paulo: Companhia das Letras, 2006. p. 90.

17 DIXON, Paul. Os contos de Machado de Assis: mais do que sonha a filosofia. Porto Alegre: Movimento, 1992. p.19.

${ }^{18}$ Idem, p. 20.
} 
reconhecimento de Jacobina da dependência imperiosa do status social e do olhar do outro para a constituição do "eu" expressaria um rito de passagem que "a maioria dos homens deve cumprir: da inexperiência ou da ingênua franqueza à máscara adulta". 19

$\mathrm{Na}$ apreciação de Augusto Meyer, a investigação metafísica de Jacobina pode ser inserida na categoria dos introvertidos que "procuram o 'eu' absoluto", "a essência de si mesmo, a verdade mais íntima do próprio ser através da autocrítica". Nesse investimento introspectivo, o analista "imagina o 'eu' como uma realidade já dada anteriormente em bloco e que pode ser conquistada sem o milagre da criação". Na impossibilidade de uma contemplação pura, o introvertido constrói uma imagem de si próprio. Assim, "como é impossível a unidade incestuosa da alma que se possui a si mesma, como há de perdurar sempre o princípio de divisão e de resistência que é a lei dialética da própria vida, o fantasma suga todo o sangue do homem e a criatura domina o criador". ${ }^{20}$ Evidencia-se, portanto, o autoengano dessa análise introspectiva na medida em que "não pode haver para o nosso espírito o desdobramento imparcial dos espelhos, pois o pensamento que se contempla ao mesmo tempo também se transfigura, retocando a própria fisionomia". ${ }^{21}$

Como se observa, a ampla tradição de leitura dedicada a esse prestigiado conto machadiano demonstra uma nítida tendência a priorizar a apreciação das investigações metafísicas relatadas pela narrativa de Jacobina em detrimento da análise das implicações que o investimento estrutural na convivência de dois narradores num mesmo espaço textual poderia refletir no delineamento do sentido da obra.

Dessa negligência de um exame consistente da elaboração formal da narrativa resultam abordagens unilaterais que manifestam um consenso acrítico em relação à excêntrica teoria de Jacobina. Exemplo expressivo dessa tendência pode ser percebido na leitura proposta pela psicanalista Marlene Bilenky, em "Uma experiência enlouquecedora: uma leitura do conto 'O espelho'", ${ }^{22}$ que afirma ter extraído para

\footnotetext{
${ }^{19}$ BOSI, Alfredo et al. Machado de Assis: antologia e estudos. São Paulo: Ática, 1982. p. 448.

${ }^{20}$ MEYER, Augusto. Machado de Assis. Rio de Janeiro: Livraria São José, 1958. p. 74-75.

${ }^{21}$ Idem, p. 76.

22 BILENKY, Marlene. Uma experiência enlouquecedora: uma leitura do conto "O espelho". In: COELHO, Márcia; FLEURY, Marcos. O bruxo do Cosme Velho: Machado de Assis no espelho. São Paulo: Alameda, 2004. p. 111-118.
} 
análise exclusivamente "o relato da experiência vivida pelo protagonista do conto". Essa perspectiva reducionista inviabiliza a possibilidade de percepção de estratégias autorais empenhadas em promover soluções maliciosas investidas de efeitos humorísticos. Consequentemente, o resultado dessa leitura desprovida de instrumentalização literária é o entusiasmo irrefletido da autora com o suposto brilhantismo da teoria metafísica de Jacobina e sugestão de atribuição do título de "precursor da psicanálise" ao autor do conto.

Uma das poucas abordagens que considera a interação entre o discurso artístico e a reflexão filosófica é apresentada por Dirce Côrtes Riedel, no livro Metáfora, o espelho de Machado de Assis: "Indiretamente, o primeiro narrador (autor implícito) dá, através das ideias de Jacobina, uma teoria do discurso poético, que não 'conjectura', nem 'opina', mas argumenta com a narrativa, que 'constrói' um modelo de vida". ${ }^{23}$ Verifica-se que a apreciação carece, no entanto, de uma problematização dessa interação entre o discurso do autor implícito e a narrativa interna de Jacobina sobre a sua experiência pessoal.

Da maneira como se assimila essa alternância e convivência entre os dois narradores depende em grande medida a leitura que se realiza da história proposta por Machado de Assis. Esse desdobramento do foco narrativo converte o tema do duplo em procedimento estrutural da obra, cabendo ao leitor o trabalho fundamental de compreender e definir a conotação que caracteriza a relação entre esses dois narradores: cumplicidade ou ironia?

A atuação do narrador-autor consiste em avaliar sutilmente a performance do narrador-personagem, influindo determinadamente sobre a maneira como será recebida a teoria metafísica enunciada. A importância dessa apreciação pode ser apreendida pela extensão da sua exposição inicial, pela sua interferência posterior para introduzir o relato da experiência de Jacobina e pela sua reaparição conclusiva no desfecho da história. Tudo se passa, portanto, como se esse porta-voz autoral detivesse todo o controle sobre o desempenho do narrador-personagem.

\footnotetext{
${ }^{23}$ RIEDEL, Dirce Côrtes. Metáfora: o espelho de Machado de Assis. Rio de Janeiro: Francisco Alves, 1974. p. 100.
} 
O juízo que se atribui à teoria enunciada por Jacobina depende essencialmente da caracterização inicial da sua persona e da maneira como se estabelece a sua relação com os demais cavalheiros. No âmbito do debate metafísico, salientam-se os propósitos ambiciosos da reunião: discutir "questões de alta transcendência" e resolver "os mais árduos problemas do universo". A audácia almejada pelo grupo equipara-se à pretensão científica do alienista Simão Bacamarte, que se imaginava capaz de divisar os limites da razão e da loucura e de promover a cura deste mal universal. ${ }^{24}$ A figura de Jacobina assume, nesse contexto, uma condição excêntrica em relação aos demais companheiros, ocasionando a hesitação do narrador quanto à definição do número exato de participantes: "Por que quatro ou cinco? Rigorosamente eram quatro os que falavam; mas, além deles, havia na sala um quinto personagem, calado, pensando, cochilando, cuja espórtula no debate não passava de um ou outro resmungo de aprovação". ${ }^{25}$

As considerações subsequentes demonstram que as motivações do silêncio de Jacobina não são decorrentes de uma personalidade introvertida, já que, posteriormente, esse suposto casmurro fez uso da palavra, "e não dois ou três minutos, mas trinta ou quarenta". Dessa forma, o seu alheamento sugere uma atitude de menosprezo para com a conversa dos demais cavalheiros, e a sua caracterização complementar é indicativa de uma figura bem-sucedida que talvez se imagine superior aos companheiros: "era provinciano, capitalista, inteligente, não sem instrução, e, ao que parece, astuto e cáustico".

A apreciação do narrador-autor perscruta também as motivações da aversão de Jacobina à discussão:

Não discutia nunca; e defendia-se da abstenção com um paradoxo, dizendo que a discussão é a forma polida do instinto batalhador, que jaz no homem, como uma herança bestial; e acrescentava que os

\footnotetext{
${ }^{24}$ Leituras de "O alienista" nessa perspectiva podem ser conferidas em: TEIXEIRA, Ivan. $O$ altar e o trono: dinâmica do poder em $O$ alienista. São Paulo: Ateliê Editorial; Editora da Unicamp, 2010; e CRESTANI, Jaison Luís. A Bastilha de Itaguaí: a estruturação do humor em "O alienista", de Machado de Assis. In: CHAVES, Vania Pinheiro. Literatura Brasileira sem fronteiras. Lisboa: Clepul, 2011. p. 122-137.

${ }^{25}$ ASSIS, Machado de. Obra completa. 4.ed. v. 2, cit., p. 345.
} 
serafins e os querubins não controvertiam nada, e, aliás, eram a perfeição espiritual e eterna. ${ }^{26}$

$\mathrm{Na}$ justificativa de Jacobina, a controvérsia é associada ao âmbito da irracionalidade, constituindo uma manifestação instintiva que reflete uma "herança bestial". Nesse sentido, o aperfeiçoamento do humano e de sua natureza espiritual implicaria na superação e na extinção desse instinto animalesco. Portanto, ao exercitar esse repúdio à discussão, Jacobina demonstra a intenção de alcançar a condição de "perfeição espiritual" característica dos serafins e querubins que se manteriam em estado de completa conformidade. Neste ponto, já se torna perceptível uma filiação desse narrador-personagem às teorias absolutistas fundamentadas na crença no progresso, que estão constantemente na mira da sátira paródica levada a efeito pela ficção machadiana.

A apreciação crítica dessa aspiração à perfeição transparece de maneira contundente no ensaio "A nova geração", em que Machado de Assis apresenta uma visada bastante adversa aos influxos do desenvolvimento das ciências modernas sobre a nova geração intelectual que se constituía:

[...] parece que um dos caracteres da nova direção intelectual terá de ser um otimismo, não só tranquilo, mas triunfante. Já o é às vezes; a nossa mocidade manifesta certamente o desejo de ver alguma coisa por terra, uma instituição, um credo, algum uso, algum abuso; mas a ordem geral do universo parece-lhe a perfeição mesma. [...] De quando em quando aparece a nota aflitiva ou melancólica, a nota pessimista, a nota de Hartmann; mas é rara, e tende a diminuir; o sentimento geral inclina-se à apoteose. ${ }^{27}$

A ponderação do posicionamento autoral contribui para evidenciar o processo de desqualificação que o narrador-autor vai imprimindo à persona do narradorpersonagem, estabelecendo um distanciamento irônico em relação ao conteúdo da teoria esboçada em sua enunciação. Nessa perspectiva de análise, pode-se dizer, portanto, que a figura do espelho e a sua função de refletir imagens de maneira invertida se

\footnotetext{
${ }^{26}$ Ibidem.

${ }^{27}$ Idem, p. 810-811.
} 
disseminam por toda a narrativa, traduzindo-se em tema e forma literária. Dessa forma, o narrador-autor se configura como um espelho mediador do relato do narradorpersonagem, de modo que a sua atuação consiste em empreender uma projeção especular e deformante da performance de Jacobina, que inverte o sentido de sua enunciação e torna questionável a seriedade de sua teoria metafísica.

Após ser desafiado por um dos companheiros, Jacobina abdicou dessa resistência obstinada à discussão e se dispôs a proferir uma apreciação da questão em debate. Convém ressaltar que, neste ponto, a conversa versava sobre a natureza da alma e dividia radicalmente os amigos reunidos: "Cada cabeça, cada sentença; não só o acordo, mas a mesma discussão, tornou-se difícil, senão impossível, pela multiplicidade de questões que se deduziram do tronco principal, e um pouco, talvez, pela inconsistência dos pareceres". É nesta conjuntura dissonante e caótica que será introduzido o discurso unívoco e ordenado de Jacobina, o qual opera uma ruptura no perfil da reunião em andamento, interrompendo a interação dialógica para instituir a autoridade de sua voz monológica e intolerante a intervenções, réplicas ou comentários.

Um dos argumentadores pediu ao Jacobina alguma opinião - uma conjetura, ao menos.

- Nem conjetura, nem opinião - redarguiu ele -; uma ou outra pode dar lugar a dissentimento, e, como sabem, eu não discuto. Mas, se querem ouvir-me calados, posso contar-lhes um caso de minha vida, em que ressalta a mais clara demonstração acerca da matéria de que se trata. Em primeiro lugar, não há uma só alma, há duas... ${ }^{28}$

Essa imposição do silêncio aos demais debatedores denuncia a postura autoritária do enunciador que se estabelece arbitrariamente como detentor de uma verdade única e absoluta. Para completar essa desqualificação sutil e irônica da performance de Jacobina, o narrador-autor retoma a voz enunciativa nas linhas finais do conto para acentuar uma vez mais essa postura impositiva e absolutista do alferes que se recusa a esperar pelas considerações dos demais companheiros a respeito da teoria e da experiência apresentadas: "Quando os outros voltaram a si, o narrador tinha descido as escadas".

\footnotetext{
${ }^{28}$ Idem, p. 346.
} 
Embora a atuação desse porta-voz autoral concentre-se na desconstrução da legitimidade do discurso de Jacobina, não se pode afirmar que a reflexão filosófica sobre a condição humana seja totalmente desprovida de pertinência. O reconhecimento de que a "aparência funciona universalmente como essência"29 e a proposição de uma concepção especular do ser humano, em que a integridade do indivíduo depende fundamentalmente do olhar do outro, constituem diretrizes conceituais que orientam a elaboração ficcional de uma parcela considerável da literatura machadiana. Nessa perspectiva, Cilene Margarete Pereira adverte, em seu livro A assunção do papel social em Machado de Assis (2007), sobre a necessidade de se identificar o sentido estrito da abordagem paródica promovida pelo conto:

A explicação de um caso acontecido quando tinha 25 anos ganha contornos cientificistas a ponto de ser apresentada (parodicamente) como "esboço de uma nova teoria da alma humana". É preciso deixar claro que aquilo que pretende ser ironizado, através da paródia, não é a própria teoria do conto - que acaba por ser usual na ficção machadiana -, mas seu arcabouço científico, ou seja, o discurso cientificista que tenta abarcar e entender a complexa alma humana por meio de aspectos tão redutores. ${ }^{30}$

A argúcia do trabalho criativo empreendido no conto está na combinação entre o desenvolvimento de uma concepção da condição humana que sustenta uma relativa coerência e a problematização da perspectiva metodológica sob a qual é enunciada. Dessa convivência confluente entre um conceito que circunda as fronteiras da pertinência e do disparate e um emissor instituído de uma performance autoritária e de uma erudição científica questionável, resulta a complexidade da obra e a dificuldade de se estabelecer uma leitura definida, capaz de deslindar de maneira satisfatória essas junções ambíguas deliberadamente construídas pela narrativa machadiana.

Verifica-se, nesse sentido, a pertinência das palavras de Merquior, para quem Machado de Assis não emprega o humor para "ilustrar" uma filosofia: ao contrário, "o seu humor - fazendo às vezes da inexistente metafísica - é filosofia; e esse fenômeno

\footnotetext{
${ }^{29}$ BOSI, Alfredo et al. Machado de Assis: antologia e estudos, cit., p. 441.

${ }^{30}$ PEREIRA, Cilene Margarete. A assunção do papel social em Machado de Assis: uma leitura do Memorial de Aires. São Paulo: Annablume; Fapesp, 2007. p. 36-37.
} 
confere uma notável modernidade à sua obra, porque nada é tão moderno quanto o eclipse das filosofias afirmativas". ${ }^{31}$

Com a análise empreendida, verificou-se, como principal procedimento estrutural do conto "O espelho", a instituição de uma distância crítica e irônica entre voz autoral e a enunciação do narrador-protagonista, que desautoriza a teoria metafísica pretensamente formulada com base numa verdade única e absoluta. De acordo com Ivan Teixeira, a subtração desse conto machadiano do "conjunto humorístico e paródico de Papéis avulsos" explica a tendência crítica de se incorrer em distorções interpretativas, que aceitam como autêntica a suposta seriedade do discurso arbitrário de Jacobina e entendem o conto "em chave filosófica, existencial e psicológica", quando a dimensão mais apropriada seria a do "sarcasmo contra esses discursos".

O estilo sério e a solenidade da argumentação, supostamente amparada em uma ponderada erudição científica, atuariam como simples "efeito de situação cômica", ${ }^{32}$ filiando-se à técnica luciânica de atribuir gravidade a doutrinas disparatadas a fim de distorcer discursos e relativizar verdades estabelecidas. Nessas teorias pretensamente científicas, são formulados conceitos e experimentações - o homem é, "metafisicamente falando, uma laranja"; a cura de uma doença singular é obtida por meio da substituição do "nariz achacado" por outro de "pura natureza metafísica" ${ }^{33}$ - que se autoenvenenam em função do distanciamento irônico mantido pela voz autoral.

Quanto a esse aspecto, a narrativa machadiana filia-se também às tendências do próprio jornal em que foi originalmente publicada. Em janeiro de 1882, a Gazeta de Notícias iniciou a publicação da série "Crônica (Palestra Científica)", que relatava os acontecimentos da semana sob um viés científico. Ocupando as páginas do folhetim dominical, nas quais foi divulgada a maioria dos contos machadianos, essas crônicas sem assinatura forneciam explicações para fenômenos científicos amparadas em episódios da política nacional. Apropriando-se da linguagem cientificista, o cronista malicioso e irreverente satiriza a tendência dominante de tudo explicar por intermédio

\footnotetext{
${ }^{31}$ MERQUIOR, José Guilherme. Gênero e estilo nas Memórias póstumas de Brás Cubas. In: ASSIS, Machado de. Obra completa em quatro volumes. v. 1, cit., p. 145.

${ }^{32}$ TEIXEIRA, Ivan. Pássaro sem asas ou morte de todos os deuses. Uma leitura de Papéis avulsos, cit., p. Xxvii.

33 A situação refere-se ao conto "O segredo do Bonzo", que pertence igualmente ao volume Papéis avulsos.
} 
desses sistemas e doutrinas metafísicas, estabelecendo um expressivo diálogo com a literatura machadiana que, de maneira alternada, ocupava esse mesmo espaço do jornal.

No que concerne à organização dos textos no volume Papéis avulsos, Ivan Teixeira assinala a importância da convivência e da sobreposição de procedimentos estruturais e efeitos de sentido que vão ressaltando a dimensão irônica e a desenvoltura paródica à medida que o leitor avança no percurso dos textos reunidos na coletânea. A experiência de leitura adquirida com as narrativas anteriores proporciona uma contribuição decisiva para o reconhecimento da ironia menipeia que permeia a elaboração ficcional de "O espelho":

\begin{abstract}
A voz menipeia, que se esconde por trás dele [Jacobina], exige a interpretação do discurso irônico, propondo a noção de que ambas as almas não passam de produto cultural. [...] Observe-se que há dois narradores no conto. Imitando o estágio inicial da alma, o primeiro compõe o cenário em que cinco cavalheiros discutem hipóteses de "alta transcendência". Por meio dessa expressão, a primeira voz parece zombar da convicção dos debatedores, dando a entender que o encontro deles não passa de um teatro de suposições, que arremeda os círculos de sábios incumbidos de inventar as essências do homem. Assim, o conto pode ser interpretado como pastiche do discurso metafísico, que substitui a necessidade de demonstração pela gravidade das afirmações impostas. ${ }^{34}$
\end{abstract}

Como se observa, essa ironia estratégica torna-se, na sua função de desqualificar o narrador e de satirizar o conteúdo de sua enunciação, um fundamento necessário para a prática da paródia, cujo reconhecimento se faz imprescindível para o funcionamento dialógico e subversivo do texto em relação aos discursos dominantes que assimila para uma desconstrução paródica.

Se a técnica humorística das obras de Luciano de Samósata consiste em atribuir seriedade a questões absurdas ou em associar um método filosófico sério a um emissor de índole burlesca e extravagante, pode-se concluir, por meio da análise crítica de "O espelho", que Machado de Assis aprimora essa estratégia literária, conduzindo-a a um nível em que as categorias do sério e do cômico se coadunam de tal maneira que

\footnotetext{
34 TEIXEIRA, Ivan. Pássaro sem asas ou morte de todos os deuses. Uma leitura de Papéis avulsos, cit., p. xxxviii-Xxxix.
} 
inviabilizam a tendência interpretativa de divisar as suas fronteiras, resolver as ambiguidades e decompor a coexistência indissociável de elementos contrapostos.

Referências:

ASSIS, Machado de. Obra completa. 4. ed. v. 2. Rio de Janeiro: Aguilar, 1979.

Papéis avulsos. Rio de Janeiro: Tipografia e litografia a vapor. Encadernação e Livraria Lombaerts \& C., 1882.

BILENKY, Marlene. Uma experiência enlouquecedora: uma leitura do conto "O espelho". In: COELHO, Márcia; FLEURY, Marcos. O bruxo do Cosme Velho: Machado de Assis no espelho. São Paulo: Alameda, 2004.

BOSI, Alfredo et al. Machado de Assis: antologia e estudos. São Paulo: Ática, 1982.

BRAYNER, Sônia. O conto de Machado de Assis. In: ASSIS, Machado de. O conto de Machado de Assis: antologia, organização e introdução de Sônia Brayner. 2.ed. Rio de Janeiro: Civilização Brasileira, 1981.

CRESTANI, Jaison Luís. A Bastilha de Itaguaí: a estruturação do humor em "O alienista", de Machado de Assis. In: CHAVES, Vania Pinheiro. Literatura Brasileira sem fronteiras. Lisboa: Clepul, 2011.

CRESTANI, Jaison Luís. O percurso criativo: do periódico ao livro. In:

Machado de Assis e o processo de criação literária: estudo comparativo das narrativas publicadas n'A Estação (1879-11884), na Gazeta de Notícias (1881-1884) e nas coletâneas Papéis avulsos (1882) e Histórias sem data (1884). 2011. 363 fls. Tese (Doutorado em Literatura Brasileira). Faculdade de Ciências e Letras - UNESP - Assis, 2011.

DIXON, Paul. Os contos de Machado de Assis: mais do que sonha a filosofia. Porto Alegre: Movimento, 1992.

GLEDSON, John. A história do Brasil em Papéis avulsos, de Machado de Assis. In:__. Por um novo Machado de Assis: ensaios. São Paulo: Companhia das Letras, 2006.

MERQUIOR, José Guilherme. Gênero e estilo nas Memórias póstumas de Brás Cubas. In: ASSIS, Machado de. Obra completa em quatro volumes. v. 1. São Paulo: Aguilar, 2008 . 
MEYER, Augusto. Machado de Assis. Rio de Janeiro: Livraria São José, 1958.

PEREIRA, Cilene Margarete. A assunção do papel social em Machado de Assis: uma leitura do Memorial de Aires. São Paulo: Annablume; Fapesp, 2007.

PEREIRA, Lúcia Miguel. Machado de Assis (Estudo crítico e biográfico). 5. ed. São Paulo: José Olympio, 1955.

REGO, Enylton de Sá. O calundu e a panaceia: Machado de Assis, a sátira menipeia e a tradição luciânica. Rio de Janeiro: Forense Universitária, 1989.

RIEDEL, Dirce Côrtes. Metáfora: o espelho de Machado de Assis. Rio de Janeiro: Francisco Alves, 1974.

ROBINSON, Christopher. Lucian and his influence in Europe. London: Duckworth, 1979.

TEIXEIRA, Ivan. $O$ altar $e$ o trono: dinâmica do poder em $O$ alienista. São Paulo: Ateliê Editorial; Editora da Unicamp, 2010.

Pássaro sem asas ou morte de todos os deuses. Uma leitura de Papéis avulsos. In: ASSIS, Machado de. Papéis avulsos. Edição e introdução de Ivan Teixeira. São Paulo: Martins Fontes, 2005.

Jaison Luís Crestani é mestre e doutor em Letras pela Unesp e pós-doutorando do Centro de Jornalismo e Editoração da Eca-Usp, onde desenvolve pesquisa com bolsa da FAPESP. É autor do livro Machado de Assis no Jornal das Famílias (São Paulo: Edusp, 2009) e de diversos artigos e capítulos de livros sobre a obra de Machado de Assis, tais como "A Bastilha de Itaguaí: a estruturação do humor em 'O alienista', de Machado de Assis". In: CHAVES, Vania Pinheiro. Literatura Brasileira sem fronteiras. Lisboa: CLEPUL, 2011. p. 122-137. E-mail: <jaisoncrestani@hotmail.com>

Recebido: $14 / 03 / 2012$

Aprovado: 18/05/2012 